\title{
THIRTY-FIRST ANNUAL LIST OF PAPERS
}

\section{READ BEFORE THE AMERICAN MATHEMATICAL SOCIETY AND SUBSEQUENTLY PUBLISHED, INCLUDING REFERENCES \\ TO THE PLACES OF PUBLICATION}

Alexander, J. W. On transformations with invariant points. Read Sept. 8, 1921. Transactions of this Society, vol. 23, No. 1, pp. 89-95; Jan., 1922.

BeAtтY, S. The algebraic theory of algebraic functions of one variable. Read Dec. 28, 1921. Proceedings of the London Mathematical Society, (2), vol. 20, No. 6, pp. 435-449; Feb., 1922.

BELl, E. T. Quelques conséquences arithmétiques de l'équation à trois termes dans la théorie des fonctions elliptiques. Read (San Francisco) June 18, 1920. Giornale di Matematiche, vol. 59, pp. 93-114; Jan.-June, 1921.

The Bernoullian functions occurring in the arithmetical applications of elliptic functions. Read (San Francisco) April 9, 1921. Messenger of Mathematics, vol. 50, No. 12, pp. 177-186; April, 1921.

- Class numbers and the form $x y+y z+z x$. Read (San Francisco) Oct. 23, 1920. Tôhoku Mathematical Journal, vol. 19, Nos. 1-2, pp. 105-116; May, 1921.

- Note on the prime divisors of the numerators of Bernoulli's numbers. Read (San Francisco) April 9, 1921. American Mathematical Monthly, vol. 28, Nos. 6-7, pp. 258-259; June-July, 1921.

- The reversion of class number relations and the total representation of integers as sums of squares or triangular numbers. Read (San Francisco) Oct. 23, 1920. Annals of Mathematics, (2), vol. 23, No. 1, pp. 56-67; Sept., 1921.

- On recurrences for sums of divisors. Read (San Francisco) Oct. 23, 1920. Quarterly Journal of Mathematics, vol. 49, No. 2, pp. 186-192; Dec., 1921.

— Sur la forme $x^{2}+3 y^{2}$ et l'équation modulaire pour la transformation du troisième ordre des fonctions elliptiques. Read (San Francisco) Oct. 23, 1920. Bulletin de la Societé Mathématique de Grèce, vol. 2, No. 2, pp. 70-76; 1921.

- An arithmetical dual of Kummer's quartic surface. Read (San Francisco) June 17, 1920. American Journal of Mathematics, vol. 44, No. 1, pp. 1-11; Jan., 1922.

- Extensions of Dirichlet multiplication and Dedekind inversion. Read (San Francisco) Oct. 22, 1921. This Bulletin, vol. 28, No. 3, pp. 111-122; March, 1922.

Arithmetical equivalents for a remarkable identity between theta functions. Read (San Francisco) Oct. 22, 1921. Mathematische Zeitschrift, vol. 13, Nos. 1-2, pp. 146-152; April, 1922.

- A revision of the Bernoullian and Eulerian functions. Read (San Francisco) April 8, 1922 . This Bulletin, vol. 28, No. 9, pp. 443-451; Dec., 1922.

Bennetr, A. A. The modular theory of polyadic numbers. Read Sept. 7, 1920. Annals of Mathematics, (2), vol. 23, No. 1, pp. 83-90; Sept., 1921.

Bernstein, B. A. The complete existential theory of Hurwitz' postulates for abelian groups and fields. Read (San Francisco) April 8, 1922. This Bulletin, vol. 28, No. 8, pp. 397-399; Nov., 1922. 
Birkhoff, G. D., and Kelloga, O. D. Invariant points in function space. Read Dec. 30, 1920, and Feb. 25, 1922. Transactions of this Society, vol. 23, No. 1, pp. 96-115; Jan., 1922.

Blichfeld , H. F. On the approximate solutions in integers of a set of linear equations. Read (San Francisco) April 9, 1921. Proceedings of the National Academy of Sciences, vol. 7, No. 11, pp. 317-319; Nov., 1921.

Blumberg, H. New properties of all real functions. Read March 26, 1921. Proceedings of the National Academy of Sciences, vol. 8, No. 10, pp. 283-288; Oct., 1922.

Brenke, W. C. An application of Abel's integral equation. Read (Southwestern Section) Nov. 29, 1913. American Mathematical Monthly, vol. 29, No. 2, pp. 58-60; Feb., 1922.

Buchanan, D. Orbits asymptotic to the straight line equilibrium points in the problem of three finite bodies. Read Dec. 28, 1918. Rendiconti del Circolo Matematico di Palermo, vol. 45, pp. 332-356; 1921.

CAJori, F. History of symbols for $n$-factorial. Read Dec. 30, 1920. Isis, vol. 3, No. 9, pp. 414-418; 1921.

- Pricked letters and ultimate ratios. Read (San Francisco) April 8, 1922. Nature, vol. 109, No. 2737, p. 477; April 15, 1922.

- Spanish and Portuguese symbols for "thousands." Read (San Francisco) Oct. 22, 1921. American Mathematical Monthly, vol. 29, No. 5, pp. 201-202; May, 1922.

- The St. Andrew's cross $(X)$ as a mathematical symbol. Read (San Francisco) Oct. 21, 1922. Mathematical Gazette, vol. 11, No. 160, pp. 136-143; Oct., 1922.

Carmichael, R. D. Boundary value and expansion problems; formulation of various transcendental problems. Read April 10, 1920. American Journal of Mathematics, vol. 43, No. 4, pp. 232-270; Oct., 1921.

- Algebraic guides to transcendental problems. Read Dec. 29, 1921. This Bulletin, vol. 28, No. 4, pp. 179-210; April-May, 1922.

- Abstract definitions of the symmetric and alternating groups and certain other permutation groups. Read April 14, 1922. Quarterly Journal of Mathematics, vol. 49, No. 3, pp."226-283; Oct., 1922.

Chitrenden, E. W. On the relation between the Hilbert space and the calcul fonctionnel of Fréchet. Read Sept. 8, 1920. Rendiconti del Circolo Matematico di Palermo, vol. 45, pp. 265-270; 1921.

- Relatively uniform convergence and the classification of functions. Read Sept. 8, 1920. Transactions of this Society, vol. 23, No. 1, pp. 1-15; Jan., 1922.

- Note on the division of a plane by a point set. Read (Southwestern Section) Nov. 26, 1921 . This Bulletin, vol. 28, No. 6, pp. 310-312; July, 1922.

Coвle, A. B. Geometric aspects of the abelian modular functions of genus four. Read Dec. 31, 1919 . Proceedings of the National Academy of Sciences, vol. 7, No. 8, pp. 245-249; No. 12, pp. 334-338; Aug. and Dec., 1921.

- Cremona transformations and applications to algebra, geometry, and modular functions. Read Dec. 31, 1919, and April 14, 1922. This Bulletin, vol. 28, No. 7, pp. 329-364; Oct., 1922.

Cole, F. N. Kirkman parades. Read Sept. 7, 1922. This Bulletin, vol. 28, No. 9, pp. 435-437; Dec., 1922.

Coolidge, J. L. Differential geometry of the complex plane. Read Dec. 29, 1920. Transactions of this Society, vol. 23, No. 2, pp. 117-134; March, 1922. 
On the existence of curves with assigned singularities. Read Dec. 27, 1922. This Bulletin, vol. 28, No. 9, pp. 451-455; Dec., 1922.

Crum, W. L. A special application of partial correlation. Read Sept. 9, 1921. Quarterly Publication of the American Statistical Association, new ser., vol. 17, No. 136, pp. 950-952; Dec., 1921.

- A measure of dispersion for ordered series. Read Sept. 9, 1921. Quarterly Publication of the American Statistical Association, new ser., vol. 17, No. 136, pp. 969-975; Dec., 1921.

- The determination of secular trend. Read Dec. 28, 1921. Quarterly Publication of the American Statistical Association, new ser., vol. 18, No. 138, pp. 210-215; June, 1922.

Curtis, M. F. Curves invariant under point-transformations of special type. Read Sept. 5, 1918. Transactions of this Society, vol. 23, No. 2, pp. 151-172; March, 1922.

Curtiss, D. R. A mechanical analogy in the theory of equations. Read Dec. 29, 1921. Science, new ser., vol. 55, No. 1417, pp. 189-194; Feb. 24, 1922.

Davis, H. T. Relating to the proof of an existence theorem for a certain type of boundary value problem. Read April 15, 1922. This Bulletin, vol. 28, No. 8, pp. 390-394; Nov., 1922.

Dickson, L. E. Some relations between the theory of numbers and other branches of mathematics. Read Dec. 30, 1920. Comptes Rendus du Congrès International des Mathématiciens, Strasbourg, pp. 41-56; 1921.

- Homogeneous polynomials with a multiplication theorem. Read Dec. 30, 1920. Comptes Rendus du Congrès International des Mathématiciens, Strasbourg, pp. 215-230; 1921.

- Arithmetic of quaternions. Read Dec. 30, 1920. Proceedings of the London Mathematical Society, (2), vol. 20, No. 3, pp. 225-232; Aug., 1921.

DoDD, E. L. Functions of measurements under general laws of errors. Read Dec. 28, 1918, Dec. 30, 1919, Sept. 8, 1921, and Dec. 28, 1921. Skandinavisk Aktuarietidskrift, Häft 3, pp. 133-158; 1922.

Douglas, J. On certain two-point properties of general families of curves. Read April 28, 1917. Transactions of this Society, vol. 22, No. 3, pp. 289-310; July, 1921.

Dresden, A. A report on the scientific work of the Chicago Section, 1899-1922. Read April 15, 1922. This Bulletin, vol. 28, No. 6, pp. 303-307; July, 1922.

Dunkes, O. The curve which with its caustic encloses the minimum area. Read (Southwestern Section) Nov. 27, 1920. Washington University Studies, scientific series, vol. 8, No. 2, pp. 183-194; 1921.

- A direct determination of the minimum area between a curve and its caustic. Read (Southwestern Section) Nov. 26, 1921. Annals of Mathematics, (2), vol. 23, No. 2, pp. 135-140; Dec., 1921.

EisenharT, L. P. Einstein static fields admitting a group $G_{2}$ of continuous transformations into themselves. Read Sept. 8, 1921. Proceedings of the National Academy of Sciences, vol. 7, No. 12, pp. 328-334; Dec., 1921.

- Ricci's principal directions for a Riemann space and the Einstein theory. Read Feb. 25, 1922. Proceedings of the National Academy of Sciences, vol. 8, No. 2, pp. 24-26; Feb., 1922.

- Condition that a tensor be the curl of a vector. Read Sept. 7, 1922. This Bulletin, vol. 28, No. 9, pp. 425-427; Dec., 1922.

Ersenhart, L. P., and Veblen, O. The Riemann geometry and its generalization. Read Dec. 28, 1921. Proceedings of the National Academy of Sciences, vol. 8, No. 2, pp. 19-23; Feb., 1922. 
Емсн, A. On the projective description of cyclides. Read Sept. 7, 1920. Tôhoku Mathematical Journal, vol. 19, Nos. 1-2, pp. 4-10; May, 1921.

Incidences of straight lines and plane algebraic curves and surfaces generated by them. Read Dec. 31, 1919. American Journal of Mathematics, vol. 44, No. 1, pp. 12-19; Jan., 1922.

- On the polar equation of algebraic curves. Read Feb. 26, 1921. Revista Matematica Hispano-Americana, vol. 4, pp. 5-9, 21-27; Feb.March, 1922.

- Kinematics in a complex domain and some geometric applications. Read Feb. 25, 1922. This Bulletin, vol. 28, No. 5, pp. 251-257; June, 1922.

Evans, G. C. Problems of potential theory. Read Sept. 4, 1919, and Dec. 30, 1920. Proceedings of the National Academy of Sciences, vol. 7, No. 3, pp. 89-98; March, 1921.

Fischer, C. A. Note on the definition of a linear functional. Read Sept. 8, 1921. Proceedings of the National Academy of Sciences, vol. 8, No. 2, pp. 26-29; Feb., 1922.

Fite, W. B. Properties of the solutions of certain functional differential equations. Read April 26, 1919, and Dec. 31, 1919. Transactions of this Society, vol. 22, No. 3, pp. 311-319; July, 1921.

Ford, W. B. On Kakeya's minimum area problem. Read Sept. 7, 1920. This Bulletin, vol. 28, Nos. 1-2, pp. 45-53; Jan.-Feb., 1922.

Fonsyth, C. H. Depreciation by a constant percentage plus a constant. Read Dec. 28, 1921. American Mathematical Monthly, vol. 29, No. 2, pp. 60-62; Feb., 1922.

FonT, T. Note on Dirichlet and factorial series. Read Dec. 31, 1919. Transactions of this Society, vol. 23, No. 1, pp. 26-29; Jan., 1922.

Frankuin, P. Two theorems on multiple integrals. Read Sept. 7, 1922. This Bulletin, vol. 28, No. 9, pp. 433-435; Dec., 1922.

Gibbens, G. E. C. A comparison of different line-geometric representations for functions of a complex variable. Read Dec. 30, 1920. Author's dissertation. Collegiate Press, Menasha, Wis., 1922.15 pp.

Gillespie, D. C. A property of continuity. Read Sept. 7, 1920. This Bulletin, vol. 28, No. 5, pp. 245-250; June, 1922.

GLenN, O. E. An algorism for differential invariant theory. Read Oct. 30, 1920. Annals of Mathematics, (2), vol. 23, No. 1, pp. 16-28; Sept., 1921. Proceedings of the National Academy of Sciences, vol. 7, No. 9, pp. 276-279; Sept., 1921.

Graustein, M. C. See Curtis, M. F.

Hart, W. L. The Cauchy-Lipschitz method for infinite systems of differential equations. Read Dec. 28, 1916. American Journal of Mathematics, vol. 43, No. 4, pp. 226-231; Oct., 1921.

- Functions of infinitely many variables in Hilbert space. Read Sept. 8, 1920. Transactions of this Society, vol. 23, No. 1, pp. 30-50; Jan., 1922.

- Summable infinite determinants. Read March 26, 1921. This Bulletin, vol. 28, No. 4, pp. 171-178; April-May, 1922.

- The method of monthly means for determination of a seasonal variation. Read April 15, 1922. Quarterly Publication of the American Statistical Association, new ser., vol. 18, No. 139, pp. 341-349; Sept., 1922.

Hazlets, O. C. Associated forms in the theory of modular covariants. Read Dec. 31, 1919. American Journal of Mathematics, vol. 43, No. 3, pp. 189-198; July, 1921. 
Hedrick, E. R., and Westfali, W. D. A. The existence domain of implicit functions. Read April 10, 1914. Mathematische Annalen, vol. 85 , pp. $74-77 ; 1922$.

Himdebrandt, T. H. Convergence of sequences of linear operations. Read Sept. 4, 1919, and Sept. 7, 1920. This Bulletin, vol. 28, Nos. 1-2, pp. 53-58; Jan.-Feb., 1922.

Hille, E. Convex distribution of the zeros of Sturm-Liouville functions. Read Dec. 28, 1921. This Bulletin, vol. 28, No. 5, pp. 261-265; June, 1922. See also A correction, This Bulletin, vol. 28, No. 9, p. $462 ;$ Dec., 1922.

Hitchсоск, F. L., and Wiener, N. A new vector method in integral equations. Read April 23, 1921. Journal of Mathematics and Physics of the Massachusetts Institute of Technology, vol. 1, No. 1, 20 pp.; Dec., 1921.

Hoar, R. S. A novel power shovel. Read April 15, 1922. Excavating Engineer, August, 1922.

Huntingtor, E. V. The mathematical theory of the apportionment of representatives. Read Dec. 28, 1920, and Feb. 26, 1921. Proceedings of the National Academy of Sciences, vol. 7, No. 4, pp. 123-127; April, 1921.

- A new method of apportionment of representatives. Read Dec. 28, 1920, and Feb. 26, 1921. Quarterly Publication of the American Statistical Association, new ser., vol. 17, No. 135, pp. 859-870; Sept., 1921.

Hurwitz, W. A. Report on topics in the theory of divergent series. Read April 23, 1921. This Bulletin, vol. 28, Nos. 1-2, pp. 17-36; Jan.-Feb., 1922

JACKSON, D. Note on a class of polynomials of approximation. Read Sept. 8, 1920. Transactions of this Society, vol. 22, No. 3, pp. 320-326; July, 1921.

- Note on the Picard method of successive approximations. Read Sept. 8, 1920. Annals of Mathematics, (2), vol. 23, No. 1, pp. 75-77; Sept., 1921.

- Note on an irregular expansion problem. Read April 23, 1921. This Bulletin, vol. 28, Nos. 1-2, pp. 37-41; Jan.-Feb., 1922.

KASNER, E. Geometrical theorems on Einstein's cosmological equations. Read Dec. 28, 1920. American Journal of Mathematics, vol. 43, No. 4, pp. 217-221; Oct., 1921.

- The solar gravitational field completely determined by its light rays. Read Sept. 8, 1921. Mathematische Annalen, vol. 85, pp. 227-236; 1922.

Kellogg, O. D. A decade of American mathematics. Read Dec. 29, 1920. Science, new ser., vol. 53, No. 1381, pp. 541-548; June 17, 1921.

- On the existence and closure of sets of characteristic functions. Read Dec. 30, 1920. Mathematische Annalen, vol. 86, Nos. 1-2, pp. 14-17; April, 1922.

- A property of certain functions whose Sturmian developments do not terminate. Read Feb. 25, 1922. This Bulletin, vol. 28, No. 8, pp. 388-389; Nov., 1922.

- See Brrkhoff, G. D.

Kempner, A. J. Ueber irreduzible Gleichungen, die unter ihren Wurzeln auch solche mit rationalem reellem Teile oder rationalem absolutem Betrag zulassen. Read (Southwestern Section) Nov. 29, 1913. Archiv der Mathematik und Physik, (3), vol. 25, No. 3, pp. 236-242; Nov., 1916. 
Polynomials and their residue systems. Read Dec. 29, 1917, and Dec. 30, 1920. Transactions of this Society, vol. 22, No. 3, pp. 267288 ; July, 1921.

Ueber die Separation komplexer Wurzeln algebraischer Gleichungen. Read Sept. 2, 1919. Mathematische Annalen, vol. 85, pp. 49-59; 1922.

KLINE, J. R. A theorem concerning connected point sets. Read Sept. 8, 1921. Fundamenta Mathematica, vol. 3, pp. 238-239; 1922.

Langman, H. Conformal transformations of period $n$ and groups generated by them. Read Dec. 28, 1920. American Journal of Mathematics, vol. 44, No. 1, pp. 54-86; Jan., 1922.

LASLEY, J. W. Some special cases of the flecnode transformation of ruled surfaces. Read Dec. 29, 1920. Author's dissertation. Chicago, University of Chicago Press, 1922.

LEFSCHETZ, S. On certain numerical invariants of algebraic varieties with application to abelian varieties. Read (Southwestern Section) Nov. 27, 1920. Transactions of this Society, vol. 22, No. 3, pp. 327-406; July, 1921; and vol. 22, No. 4.; Oct., 1921.

Lehmer, D. N. On the computation of interest on certain kinds of investments. Read (San Francisco) April 9, 1921. American Journal of Accountancy, July, 1921.

LIPKA, J. On the geometry of motion in curved $n$-space. Read April 23, 1921. Journal of Mathematics and Physics of the Massachusetts Institute of Technology, vol. 1, No. 1, 21 pp.; Dec., 1921.

- Transformations of trajectories on a surface. Read Dec. 28, 1920. Annals of Mathematics, (2), vol. 23, No. 2, pp. 101-111; Dec., 1921.

Mclennan, J. C. Atomic nuclei. Read Dec. 29, 1921. Science, new ser., vol. 55, No. 1418, pp. 219-232; March 3, 1922.

MACDUFFEe, C. C. Invariantive characterizations of linear algebras with the associative law not assumed. Read March 25, 1921. Transactions of this Society, vol. 23, No. 2, pp. 135-150; March, 1922.

MacMillan, W. D. The moment of inertia in the problem of $n$ bodies. Read April 10, 1920. This Bulletin, vol. 28, No. 4, pp. 165-168; April-May, 1922.

MacNeish, H. F. Das Problem der 36 Offiziere. Read Dec. 28, 1921. Jahresbericht der Deutschen Mathematiker-Vereinigung, vol. 30, Nos. 9-12, pp. 151-155; 1921.

Mathews, R. M. Two new constructions of the strophoid. Read Dec. 28, 1920. American Mathematical Monthly, vol. 29, No. 2, pp. 55-58; Feb., 1922.

- A general construction for circular cubics. Read Oct. 28, 1922. American Mathematical Monthly, vol. 29, No. 5, pp. 202-204; May, 1922.

Mrluer, G. A. An overlooked infinite system of groups of order $p q^{2}$. Read March 26, 1921. Proceedings of the National Academy of Sciences, vol. 7, No. 5, pp. 146-148; May, 1921.

- Substitutions commutative with every substitution of an intransitive group. Read Dec. 28, 1921. This Bulletin, vol. 28, No. 4, pp. 168-170; April-May, 1922.

Moore, C. N. Sur l'équivalence des méthodes de sommation de Cesàro et de Hölder pour les limites multiples. Read April 14, 1922. Comptes Rendus de l'Académie des Sciences, vol. 175, No. 9, pp. 397-398; Aug. 28, 1922.

- Generalized limits in general analysis. Read Dec. 28, 1918. Proceedings of the National Academy of Sciences, vol. 8, No. 10, pp. 288293; Oct., 1922. 
Moore, R. L. On the relation of a continuous curve to its complementary domains in space of three dimensions. Read Oct. 29, 1921. Proceedings of the National Academy of Sciences, vol. 8, No. 3, pp. 33-38; March, 1922.

- Concerning connectedness im kleinen and a related property. Read Sept. 8, 1921. Fundamenta Mathematica, vol. 3, pp. 232-237; 1922.

Morenus, E. M. Geometric properties of the system of all curves of constant pressure in a plane field of force. Read Feb. 25, 1922. Author's dissertation. Philadelphia, Winston, 1922.

Moritz, R. E. Ueber gewisse Infinitesimaloperationen der höheren Operationsstufen. Read (San Francisco) Oct. 22, 1921. Tôhoku Mathematical Journal, vol. 21, Nos. 1-2, pp. 51-64; July, 1922.

OwEns, F. W. On the apportionment of representatives. Read Feb. 26, 1921, and April 23, 1921. Quarterly Publication of the American Statistical Association, new ser., vol. 17, No. 136, pp. 958-968; Dec., 1921.

Pell, A. J. Linear equations with two parameters. Read Oct. 25, 1919. Transactions of this Society, vol. 23, No. 2, pp. 198-211; March, 1922.

Poor, V. C. On the theorems of Green and Gauss. Read April 23, 1921. American Journal of Mathematics, vol. 44, No. 1, pp. 20-24; Jan., 1922.

Porter, M. B. A two-way infinite series for Lebesgue integrals. Read Sept. 9, 1921. This Bulletin, vol. 28, No. 3, pp. 105-108; March, 1922.

Post, E. L. Introduction to a general theory of elementary propositions. Read April 24, 1920. American Journal of Mathematics, vol. 43, No. 3, pp. 163-185; July, 1921.

RICE, L. H. A certain type of product and the combinatory analysis involved in its expansion. Read Feb. 26, 1921, and Oct. 29, 1921. Journal of Mathematics and Physics of the Massachusetts Institute of Technology, vol. 1, No. 2, pp. 86-88; March, 1922.

- On the expression of the sum of any two determinants as a determinant of more dimensions. Read Oct. 28, 1922. Journal of Mathematics and Physics of the Massachusetts Institute of Technology, vol. 1, No. 3, pp. 160-166; April, 1922.

RItT, J. F. Periodic functions with a multiplication theorem. Read Feb. 26, 1921. Transactions of this Society, vol. 23, No. 1, pp. 16-25; Jan., 1922.

- Prime and composite polynomials. Read Oct. 29, 1921. Transactions of this Society, vol. 23, No. 1, pp. 51-66; Jan., 1922.

Roever, W. H. Brilliant point phenomena. Read (Southwestern Section) Nov. 27, 1915. Washington University Studies, scientific series, vol. 8 , No. 2, pp. 131-160; 1921.

- Lines of illumination caused by the passage of light through a screen. Read (Southwestern Section) Nov. 27, 1915. American Mathematical Monthly, vol. 29, No. 4, pp. 149-156; April, 1922.

Rowe, J. E. The power of a modern gun and of thunder. Read Sept. 9, 1921. Scientific American, vol. 125, No. 11, p. 49; Nov., 1921.

Ruthedge, G. Explicit determination of Cotes' coefficients for polynomial area. Read April 10, 1920. Journal of Mathematics and Physics of the Massachusetts Institute of Technology, vol. 1, No. 2, pp. 78-85; March, 1922.

Sakellariou, N. Sur la théorie de la flexion. Read April 24, 1920. Bulletin de la Société Mathématique de Grèce, vol. 2, No. 1, pp. 32-36; May, 1920.

Schmid, K. The theory of functions of one Boolean variable. Read Sept. 7, 1922. Transactions of this Society, vol. 23, No. 2, pp. 212-222; March, 1922. 
Slaught, H. E. Subsidy funds for mathematical projects. Read Dec. 29, 1921. Science, new ser., vol. 55, No. 1415, pp. 146-148; Feb. 10, 1922.

Speiser, A. Die Zerlegung von Primzahlen in algebraischen Zahlkörpern. Read April 14, 1922. Transactions of this Society, vol. 23, No. 2, pp. 173-178; March, 1922.

STOUFFer, E. B. A calculation of the invariants and covariants of ruled surfaces. Read (Southwestern Section) Nov. 27, 1920. Kansas University Science Bulletin, vol. 13, No. 5, pp. 59-71; May, 1920.

- Semi-covariants of a general system of linear homogeneous differential equations. Read (Southwestern Section) Nov. 27, 1920. Proceedings of the National Academy of Sciences, vol. 7, No. 9, pp. 273-276; Sept., 1921.

TAylor, J. S. The analytic geometry of complex variables with some applications to function theory. Read Dec. 29, 1920. Comptes Rendus du Congrès International des Mathématiciens, Strasbourg, pp. 388-396; 1921.

VANDIVER, H. S. On Kummer's memoir of 1857 concerning Fermat's last theorem. Read Oct. 30, 1920. This Bulletin, vol. 28, No. 8, pp. 400-407; Nov., 1922.

VAN VLECK, E. B. An extension of Green's lemma to the case of a rectifiable boundary. Read March 29, 1919. Annals of Mathematics, (2), vol. 22, No. 4, pp. 226-237; June, 1921.

Veblen, O. Analysis situs. Read Sept. 6-8, 1916. The Cambridge Colloquium, 1916, Part II, $8+150$ pp.; New York, 1922. See Eisenhart, L. P.

WALsh, J. L. On the transformation of convex point sets. Read Sept. 7, 1920. Annals of Mathematics, (2), vol. 22, No. 4, pp. 262-266; June, 1921.

Some two-dimensional loci connected with cross ratios. Read Sept. 7, 1920, and Sept. 9, 1921. Transactions of this Society, vol. 23, No. 1, pp. 67-88; Jan., 1922.

- A generalization of normal congruences of circles. Read Dec. 27, 1922. This Bulletin, vol. 28, No. 9, pp. 456-462; Dec., 1922.

WALSH, J. L., and WIENER, N. The equivalence of expansions in terms of orthogonal functions. Read Dec. 28, 1921. Journal of Mathematics and Physics of the Massachusetts Institute of Technology, vol. 1, No. 2, pp. 103-122; March, 1922.

Webster, A. G. On steering an automobile around a corner. Read Sept. 8, 1921. Proceedings of the National Academy of Sciences, vol. 8, No. 5, pp. 100-106; May, 1922.

WedDERBurn, J. H. M. The automorphic transformation of a bilinear form. Read Dec. 28, 1920. Annals of Mathematics, (2), vol. 23, No. 2, pp. 122-134; Dec., 1921.

Westrall, W. D. A. See Hedrick, E. R.

Whirtemore, J. K. Minimal surfaces containing straight lines. Read April 26, 1919. Annals of Mathematics, (2), vol. 22, No. 4, pp. 217225; June, 1921.

- Reciprocity in a problem of relative maxima and minima. Read April 24, 1920. American Journal of Mathematics, vol. 43, No. 4, pp. 271-290; Oct., 1921.

Wiener, N. The average of an analytic functional. Read Dec. 28, 1920. Proceedings of the National Academy of Sciences, vol. 7, No. 9, pp. 253-260; Sept., 1921. 
- The average of an analytic functional and the Brownian movement. Read Dec. 28, 1920. Proceedings of the National Academy of Sciences, vol. 7, No. 10, pp. 294-298; Oct., 1921.

- A new type of integral expansion. Read April 14, 1922. Journal of Mathematics and Physics of the Massachusetts Institute of Technology, vol. 1, No. 3, pp. 167-176; April, 1922.

See Hitchcock, F. L., WaLsh, J. L.

Wilczynski, E. J. Charakteristische Eigenschaften der isotherm-konjugierten Kurvennetze. Read Dec. 29, 1920. Mathematische Annalen, vol. 85 , pp. 208-212; 1922.

Woods, R. The elliptic modular functions associated with the elliptic norm curve $E^{7}$. Read April 14, 1922. Transactions of this Society, vol. 23, No. 2, pp. 179-197; March, 1922.

Zeldin, S. D. Some hydrodynamic aspects of group theory. Read Sept. 9, 1921. Journal of Mathematics and Physics of the Massachusetts Institute of Technology, vol. 1, No. 1, 9 pp.; Dec., 1921.

- On the structure of finite continuous groups with one two-parameter invariant subgroup. Read Dec. 28, 1920. Annals of Mathematics, (2), vol. 23, No. 2, pp. 112-117; Dec., 1921.

- On the simplification of the structure of finite continuous groups with more than one two-parameter invariant subgroup. Read Feb. 26, 1921. Annals of Mathematics, (2), vol. 23, No. 2, pp. 118-121; Dec., 1921.

Commutativity of contact transformations of mechanics. Read Dec. 28, 1921. Journal of Mathematics and Physics of the Massachusetts Institute of Technology, vol. 1, No. 3, pp. 157-159; April, 1922.

- Note on steady fluid motion. Read Sept. 7, 1922. This Bulletin, vol. 28, No. 6, pp. 313-314; July, 1922. 